\title{
The Effect of Corporate Governance Mechanism on Financial Distress in State-Owned Enterprises
}

\author{
Fuad Ahsan ${ }^{1}$, Otto Randa Payangan ${ }^{2}$, Idayati Nursyamsi ${ }^{3}$ \\ \{vuadalviaro@gmail.com¹, ottopayangan@unhas.ac.id ${ }^{2}$, idayanti@unhas.ac.id ${ }^{3}$ \} \\ Universitas Hasanuddin, Makassar, Indonesia ${ }^{1,2,3}$
}

\begin{abstract}
This study aims to analyze the influence of corporate governance on a company's financial distress. In discussing corporate governance specifically, it is seen from specific aspects which include the independence board, CEO ownership, executive director ownership, family ownership, independent audit committee, and audit committee expertise in terms of the financial condition of the affected company. There are 16 stateowned enterprises that are presented in the Indonesia Stock Exchange, where 8 companies are indicated to be depressed and 8 companies that are indicated to be healthy in the 2015-2018 period. After doing research, it was found that corporate governance variables did not have a significant effect on corporate financial difficulties, such as the return on asset (ROA) variable that influenced the company's financial distress variables, so it can be explained how corporate governance cannot be used as a tool to improve performance corporate finance in Indonesia.
\end{abstract}

Keywords: Good Corporate Governance, Independence Board, CEO Ownership, Executive Director Ownership, Family Ownership, Independent Audit Committee and Audit Committee Expertise.

\section{Introduction}

In the current business environment, the issue of corporate governance continues to increase, becoming a major focus for regulators, investors, creditors, and other stakeholders throughout the world financial markets [1]. The issue of corporate governance is attracting attention because of several Asian countries affected by the financial crisis which began in 1997; many experts are of the opinion that weaknesses in corporate governance are one of the main sources of economic insecurity which causes the deterioration of the economies of these countries in 1997 and 1998. Even in the UK in the late 1980s corporate governance issues became a public concern as a result of the publicity of corporate problems such as creative accounting issues, company bankruptcy on a very large scale, misuse of stakeholder funds by managers, limited role of auditors, the unclear link between executive compensation and company performance, mergers and acquisitions is detrimental to the economy as a whole.

As a result, good corporate governance is increasingly considered important; this is due to the opening of large-scale financial scandals such as the scandal of the president director of PLN, Pertamina's Managing Director, Division II Head of PT Waskita Karya, Head of Finance, PT Waskita Karya, and Managing Director of PT Pelindo which was revealed early in 2019. Issues regarding corporate governance in the current business environment continue to increase and become the main focus for regulators, investors, creditors, and other stakeholders in all world financial markets [1]. 
Predicting the company's financial distress is important to obtain early signs of bankruptcy as part of an early warning system for management. Management can anticipate and take steps to improve company performance. For stakeholders, especially shareholders and creditors, this prediction is the basis for making decisions to face various bad possibilities related to the company's financial stability in the future.

Financial distress or financial difficulties will be experienced by the company before bankruptcy occurs. Financial distress is a condition of the economic crisis in which the company suffers losses in recent years because it is considered unable to pay obligations when due. The economic downturn in the company needs to be watched out by the management. Therefore, management should take action by making early predictions in order to improve the company's economic conditions. Financial distress arises from various situations until the company faces the problem of economic difficulties.

The crisis in Indonesia has led to a multidimensional level. The most prominent thing is in the economic aspect, namely the decline in economic activity because more companies are being liquidated and an increasing number of unemployed workers. The cause of this crisis is not because of weak economic fundamentals, but because foreign private debt has reached a considerable amount. The fall in the rupiah is currently the most difficult in the two decades after the 1998 crisis. This has led to a prolonged crisis that eliminates estimates from speculation and maturities on large amounts of foreign loans at the same time, which also increases dollar demand. Additionally, many natural disasters have resulted in the exchange rate of the rupiah getting weaker. Things that are not much different also happen to various companies in Indonesia that experience financial conditions that are not good. Indications of differences in interests between internal and external parties may result in misuse of financial statements.

BUMN (Public Company) is a State-Owned Enterprise that is an important pillar in the driving force of the national economy. According to Law Number 19 of 2003, BUMN has a definition of a business entity in which entire or most of its capital is owned by the state through direct participation from the separated state assets. All BUMN entities have been under the supervision and management of the Ministry of BUMN since 2001. The Ministry of BUMN in carrying out its functions, is led by the Minister of BUMN. The government issued Presidential Instruction (Inpres) No.17 of 1967 concerning Direction and Simplification of State Enterprises. The Inpres classifies state-owned companies into three forms, namely Perusahaan Perseroan (Persero), public companies (Perum) and Perusahaan Jawatan (Perjan). Companies out of the total number are not yet listed on the Indonesia Stock Exchange (IDX). The Persero is a BUMN in the form of a limited liability company whose capital is in the form of shares. The ownership of these shares is wholly or partly, with a minimum of $51 \%$ owned by the government or country, which has the main goal of pursuing profits.

\section{Research Methodology}

\subsection{Research Approach}

This research uses a quantitative approach that is using deductive thinking, which shows that thinking in research is based on general or universal patterns and then leads to narrower or specific patterns [5]. In discussing corporate governance specifically, this can be seen from the specific aspects which include the independence board, CEO ownership, executive director 
ownership, family ownership, independent audit committee, and audit committee expertise in terms of the financial condition of companies affected in state-owned companies.

\subsection{Research Types}

Based on the research objectives, this research is an explanative research. This explanatory research is a study that tests a prediction of a theory or principle [3]. The purpose of the explanatory research also explains the pattern of relationships that occurs between two or more variables, in addition, this study tries to see and explain the effect of corporate governance on the possibility of companies experiencing financial distress.

Based on the time dimension, this research is a pooled cross-section (panel data) study. Panel data observes the same thing in two or more time periods as indicated by the use of time-series data. Panel data can explain two kinds of information, namely: cross-section information on differences between subjects and time series information that reflects changes in the subject of time. When both of the information is available, panel data analysis can be used. In this study, data from the BUMN companies' financial statements in 2013-2018 will be observed.

This research observed the data collection techniques, including quantitative data collection techniques, namely existing statistics [3] in the form of financial statements published by the company. In addition, this study uses two studies in data collection, namely through library studies and field studies.

\subsection{Population and sample}

The population in this study is all state-owned companies that publish GCG and financial reports as well as those listed on the Indonesia Stock Exchange (IDX) from 2013 and are still registered until 2018. The samples in this study were selected using the purposive or judgmental sampling method, namely sampling based on some criteria. Maudos \& Solís (2009) states that purposive or judgmental sampling allows the use of researchers' judgment in sample selection to answer research questions and also adjusts to the research objectives to be achieved [4]. To investigate the influence between corporate governance and the possibility of companies experiencing financial distress, this study focused on the time period from 20152018.

The researcher uses negative Earning Per Share (EPS) value over a long period of time. In this study, six consecutive years in a company as a key indicator. EPS is a reflection of how a company conducts its operations. However, based on Elloumi \& Gueyié (2001), the classification of companies that is in financial distress in this study, if the company experiences negative EPS for three years in a row, the latest paper has classified the companies that experience financial distress on an annual basis [5].

A company is classified as a company that experiences financial distress in 2015 if the company has experienced negative EPS in the two years before 2015, and includes 2015 itself. Likewise, for 2016, 2017 and 2018, the procedure is the same as in 2018. In short, for a company that can be included in the final sample of this study must meet the financial distress criteria, experiencing negative EPS for six consecutive years from 2013 to 2018 due to this research focuses on the 2013-2018 period. 


\subsection{Research variable}

The dependent variable in this study is a dummy variable. In Ulum, Ghozali, \& Chariri (2008), dummy or qualitative variables indicate the presence or absence of quality or an attribute. The way to quantify the qualitative variables above is by forming an artificial variable with a value of 1 or 0.1 indicates the existence of an attribute and 0 indicates the absence of an attribute. Then the scoring in this study is a value of 1 for a distressed company and 0 (zero) for a healthy company [6].

The independent variable in this study is related to the independence board, CEO ownership, executive director ownership, family ownership, independent audit committee, and audit committee expertise corporate of governance. Board independence is a proportion of the number of independent directors to the total number of directors on the board. CEO ownership is a comparison percentage of common shares owned by the company's CEO or managing director with the total number of common shares outstanding. If the owner is less than $5 \%$, then it will be given the number 1 , and 0 if vice versa. Executive director ownership is a proportion of the ordinary shares owned by all executive directors with the total number of ordinary shares owned by the company in circulation. If the percentage of ordinary shares owned is less than $5 \%$, then it will be given the number 1 , and 0 if vice versa. Family ownership is a proportion of ordinary shares owned by family members where family members here have a relationship with the board compared to the total outstanding shares. Share ownership of less than $10 \%$. Then it will be given the number 1 and 0 if vice versa. An independent audit committee is a comparison of the number of independent directors on the audit committee with the total number of the company's audit committee members. Audit committee expertise, if there are no members of the audit committee who have expertise or knowledge about finance, then it will be given the number 1 , and 0 if vice versa.

The control variable used in this study is ROA (return on assets) measured by comparing the net income with the company's total assets. This ratio is able to provide benchmarks to assess the effectiveness and efficiency of the company's operational activities. Another variable used in this study is leverage. The leverage variable is seen from the total liabilities of the company divided by the total assets used as a proxy in seeing the company's ability to manage its assets to be able to pay its obligations.

\subsection{Research Models}

Logistic regression is a research tool used in research because it requires dummy variables that are part of the dependent variable and independent variables. The dependent variable used in this research is a binary variable, that is whether the company is experiencing financial distress or not. The independent variables used in this model are board independence, CEO ownership, executive director ownership, family ownership, independent audit committee, and audit committee expertise. Then the estimated logistic regression models that will be used in this study are as follows:

$$
F D=B I N D+C E O W N+E D O W N+F O W N+A C I N D+A C E X P+L E V+R O A+\varepsilon_{t}
$$




\subsection{Data analysis techniques}

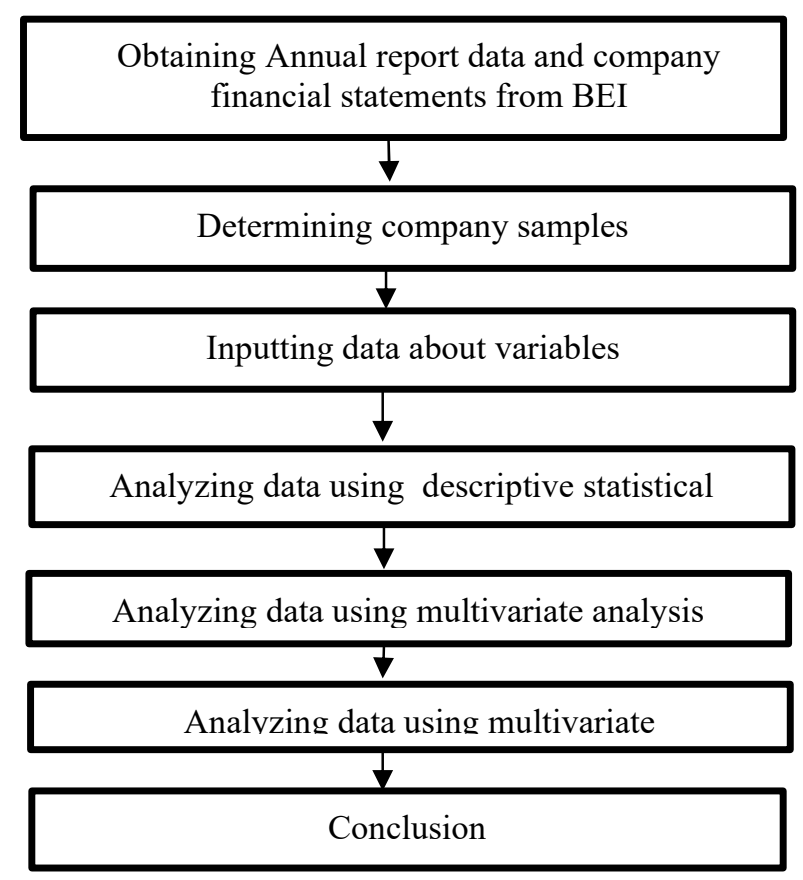

Fig 1. Data analysis technique

\section{Result and Discussion}

Table 1. Descriptive statistics of distress firms and healthy firms

\begin{tabular}{ccccc}
\hline Distress & BIND & ACIND & LEV & ROA \\
\hline Mean & 0.12777 & 0.10764 & 0.33902 & -0.05017 \\
Maximum & 0.03344 & 0.11111 & 0.09293 & 0.01358 \\
Minimum & 0.11111 & 0.00000 & 0.00082 & -0.34452 \\
Std. Dev. & 0.02475 & 0.01964 & 0.02690 & 0.06453 \\
Observations & 32 & 32 & 32 & 32 \\
Healthy & BIND & ACIND & LEV & ROA \\
Mean & 0.35714 & 0.11111 & 0.18579 & 0.02413 \\
Maximum & 0.03344 & 0.11111 & 0.24629 & 0.10407 \\
Minimum & 0.08333 & 0.11111 & 0.05554 & -0.00125 \\
Std. Dev. & 0.02436 & 0.00000 & 0.05195 & 0.02411 \\
Observations & 32 & 32 & 32 & 32 \\
\hline
\end{tabular}


Based on Table 1, the minimum board proportion (BIND) owned by distressed firms is $33.3 \%$, and a maximum of $50 \%$ of all boards of commissioners with an average of $38.3 \%$ and a standard deviation of 0.02475 whereas board independence (BIND) owned by healthy firms has a minimum proportion of $25 \%$ and a maximum of $50 \%$ with an average of $35.7 \%$ and a standard deviation of 0.02436 . The descriptive statistical results show that the average board independence composition of distressed firms and healthy firms is almost the same and there is no significant difference. The proportion of independent audit committees (ACIND) in distressed firms is at least $0 \%$ and a maximum of $33.3 \%$, with an average of $32.2 \%$ and a standard deviation of 0.01964 . The proportion of independent audit committees in healthy firms has a minimum, maximum, and average value of $33.3 \%$. The descriptive statistical results above show that distressed firms and healthy firms have almost the same proportion of independent audit committees with no significant difference.

The maximum leverage value (LEV) of distressed firms is 0.09293 with an average of 0.33902 while in healthy firms, the maximum value of the leverage is only 0.24629 , with an average of 0.18579 . These results indicate that the use of debt as a source of funding for distressed firms is greater than for healthy firms, as indicated by the average value of leverage that is greater in distress firms. The minimum value of return on assets (ROA) owned by distressed firms is -0.34452 , and the maximum one is 0.01358 with an average of -0.05017 while for healthy firms, a minimum of -0.00125 and a maximum of 0.10407 with an average of 0.02413 . From the results of descriptive statistics, the above can be seen that the average indication of ROA in healthy companies is greater than companies that are distressed.

Table 2. Descriptive statistics of the entire study sample

\begin{tabular}{ccccc}
\hline & BIND & ACIND & LEV & ROA \\
\hline Mean & 0.12341 & 0.10937 & 0.262409 & -0.013016 \\
Maximum & 0.03344 & 0.11111 & 0.09293 & 0.10407 \\
Minimum & 0.08333 & 0.00000 & 0.00082 & -0.34452 \\
Std. Dev. & 0.02436 & 0.13889 & 0.30623 & 0.06113 \\
Observations & 64 & 64 & 64 & 64 \\
\hline
\end{tabular}

From the results of descriptive statistical testing, the average board independence in the 16 companies that became the sample of this study in 2015-2018 was 0.37024 while the minimum board independence is 0.250 and the maximum is 0.500 . Based on the average value of board independence, it is known that the average proportion of the number of independent commissioners compared to the total board of commissioners is $37.024 \%$. On other word, some companies already have a proportion of independent commissioners exceeding one-third of the commissioners in a company and have also fulfilled the provisions made by The Indonesia Stock Exchange, which is at least 30\% of the Board of Commissioners is an Independent Commissioner. The standard deviation of the board independence variable is 0.073097 , which means there is a deviation of 0.073097 against the average calculation. The standard deviation of the independent audit committee variable is 0.041667. Obtained deviation on the average calculation with a value of 0.041667 . In addition, the results of 0.7872292 or $78.72 \%$ are required from the ratio between the total assets of 16 companies as a whole. The standard deviation of the LEV variable is 0.62147234 . This means that there is a deviation of 0.62147234 to the average calculation. The minimum value of leverage is 0.00247 , while the maximum value is 2.78814 . Based on the results of the average value of 
leverage, we can find out that the companies included in this research sample funded most of their assets from debt, although there are also companies that only use a little debt as a source of funding during the study period. The average return on assets for these 16 companies is 0.0390498 , so it can be said that the companies that are sampled companies are still not effective in managing their assets. Where the minimum value of the ROA is -1.03358 and the largest value is 0.31223 . The standard deviation of the ROA variable is 0.18341362 . This means that there is a deviation of 0.18341362 against the average calculation.

Table 3. Results Correlation between independent variables

\begin{tabular}{ccccccccr}
\hline Variabel & BIND & CEOWN & EDOWN & FOWN & ACIND & ACEXP & LEV & ROA \\
\hline BIND & 1.0 & & & & & & & \\
& $(0.000)$ & & & & & & & \\
CEOWN & -0.018 & 1,0 & & & & & & \\
& $(0.944)$ & $(0.000)$ & & & & & & \\
EDOWN & 0.018 & $2.000^{* *}$ & 1,0 & & & & & \\
& $(0.944)$ & $(0.000)$ & $(0.000)$ & & & & \\
FOWN & 0.028 & $1.810^{* *}$ & $0.905^{* *}$ & 1,0 & & & \\
& $(0.910)$ & $(0.000)$ & $(0.000)$ & $(0.000)$ & & & \\
ACIND & $-0.450^{*}$ & -0.082 & -0.041 & -0.037 & 1,0 & & \\
& $(0.074)$ & $(0.750)$ & $(0.375)$ & $(0.387)$ & $(0.000)$ & & \\
ACEXP & -0.018 & $-0.696^{* *}$ & $-0.696^{* *}$ & $-0.818 * *$ & 0.134 & 1,0 & & \\
& $(0.946)$ & $(0.004)$ & $(0.004)$ & $(0.000)$ & $(0.600)$ & $(0.000)$ & & \\
LEV & -0.134 & -0.206 & 0.206 & 0.196 & -0.312 & 0.196 & 1,0 & \\
& $(0.300)$ & $(0.418)$ & $(0.418)$ & $(0.442)$ & $(0.218)$ & $(0.440)$ & $(0.000)$ & \\
ROA & $-0.484^{*}$ & -0.262 & -0.262 & -0.206 & -0.084 & 0.022 & $-0.730^{* *}$ & 1.0 \\
& $(0.054)$ & $(0.302)$ & $(0.302)$ & $(0.418)$ & $(0.742)$ & $(0.932)$ & $(0.004)$ & $(0.000)$ \\
\hline
\end{tabular}

In table 3 found an indication that the correlation where the value of $r$ is equal to 1000 , with a $\mathrm{p}$ value of less than 0.01 , from here it is found that there is a correlation of independent variables that form a perfect positive correlation between the ownership variable with the CEO and executive ownership, this proves that the company has share ownership with the CEO is then directly proportional to managerial ownership as well. The existence of this perfect correlation causes redundancy in the matrix design on the results of the subsequent logistic regression, where EDOWN $=\mathrm{CEOWN}$. There is also a strong significant positive correlation between CEOWN and family ownership (FOWN) $(\mathrm{r}=0.905$, p-value $<0.01)$ and executive director ownership (EDOWN) and FOWN $(r=0.905$, $\mathrm{p}$ - value $<0.01)$. This indicates that the company owned by the CEO is also owned by the managerial and there is a possibility that the CEO or executive director member of the company is also a family member.

The relationship between audit committee expertise and executive expertise committee with CEO ownership of ( $\mathrm{r}-0.696$ with a $\mathrm{p}$ value less than $<0.01$ ), executive director ownership with (r-value -0.696 with a $\mathrm{p}$-value of less than $<0.01$ ), and family ownership with (r-value of -0.818 with p-value less than $<0.01$ ). From the above data it can be seen that it shows negative with significant accuracy. Then demonstrated experience and skills with a high index audit board inversely proportional to managerial board ownership and ownership is still low. Board independence (BIND) and return on assets (ROA) have a moderate but significant negative relationship $(r=-0.484$, p-value $<0.05)$ which shows that a company with 
a higher board independence will reduce the company's performance which is reflected in the value ROA. Board independence (BIND) with an independent audit committee (ACIND) also has a negative but significant relationship $(r=-0.450$, $\mathrm{p}$-value $<0.05)$ which shows that a company with a higher board independence does not cause the proportion of independent commissioners on the committee audits are also getting higher. Leverage and ROA have a moderate but significant negative relationship $(\mathrm{r}=-0.730$, p-value $<0.01)$ meaning that companies with higher leverage will have lower ROA, this result is in accordance with the findings by Daily \& Dalton (1994), Charitou, Lambertides, \& Trigeorgis (2007) and (Yusoff, Mohamad, \& Darus (2014). [6], [7], [8]

In Table 3 the correlation between the dependent and independent variables and the control variables in this study can be seen. The results of the correlation analysis between the independent variables and the independent variables stated that there was a significant relationship between the dependent variable and the independent variables CEOWN, EDOWN, FOWN, and the two control variables.

Distress conditions have a significant positive correlation with CEOWN and EDOWN, which means companies that are distressed by shareholders by the CEO and by managerial share ownership less than $5 \%$ of the total outstanding shares. The significant positive correlation between the condition of distress and FOWN indicates the ownership of shares by family members who have a relationship with members of the board of commissioners is below $10 \%$ of the total shares of the company in circulation.

Table 4. Results of correlations between the dependent variable and the independent variable

\begin{tabular}{|c|c|}
\hline Variable & Distress \\
\hline BIND & $\begin{array}{c}0.362 \\
(0.154)\end{array}$ \\
\hline CEOWN & $\begin{array}{l}0.644^{* *} \\
(0.010)\end{array}$ \\
\hline FOWN & $\begin{array}{l}(0.010) \\
0.582 * * \\
(0.020)\end{array}$ \\
\hline ACIND & $\begin{array}{l}-0.252 \\
(0.322)\end{array}$ \\
\hline ACEXP & $\begin{array}{c}0.152 \\
(0.552)\end{array}$ \\
\hline ROA & $\begin{array}{l}1.492 * * \\
-1.226 \\
(0.000)\end{array}$ \\
\hline
\end{tabular}

Significant correlations were also found between the two control variables with pressure conditions with ( $\mathrm{r}$ value at leverage of 1.492 and a $\mathrm{p}$ value of less than $<0.01$ ) while the return on assets (ROA) with ( $\mathrm{r}$ value of -1.226 and a $\mathrm{p}$ value of less than $<0.01)$. This indicates that companies that are in a state of distress have a higher level of leverage which results in a decrease in the value of return on assets (ROA). This finding supports the results found by Charitou et al. (2007) and Yusoff et al. (2014) where companies that are experiencing 
financial difficulties are found to have a negative correlation with company performance (ROA) and are positively related to leverage.

\subsection{Multivariate Analysis}

Table 5. Classification tables block 0

\begin{tabular}{cccccc}
\hline \multirow{2}{*}{ Objected } & & \multicolumn{2}{c}{ Predicted } & \\
& & & Distresse`d firm & Percentage \\
\hline \multirow{3}{*}{ Step } & Distressed & 0 & 0 & 1 & 0.0 \\
& 1 & 0 & 32 & 75.0 \\
& Overall Percentage & & & 35.0
\end{tabular}

The table shows a classification table that presents information about the accuracy of the predictions. By using only constants, the accuracy of the prediction is $35 \%$, while Table 5, variables in the equation, displays the Wald test. If using only a constant without entering the independent variable, the value is not significant at $\alpha=5 \%$ in influencing companies experiencing financial distress.

Table 6. Variables in the equation

\begin{tabular}{cccccccc}
\hline & & B & S.E. & Wald & df & Sig. & Exp(B) \\
\hline Step & Constant & 0.000 & 0.500 & 0.000 & 1 & 1.00 & 1.00 \\
\hline
\end{tabular}

Tabel 7. Hosmer and Lemeshow test

\begin{tabular}{cccc}
\hline Step & Chi-square & df & Sig. \\
\hline & 7.605 & 8 & 0.434 \\
\hline
\end{tabular}

Based on the table above. it shows that the value of the results of the Hosmer and Lemeshow's Goodness of Fit test shown in the Chi-square value is 7.605 with a significance of 0.438 . At $\alpha$ of 0.05 with a significance level of 0.434 is greater than the $\alpha$ value of $5 \%$. It can be concluded that $\mathrm{H} 0$ is not rejected (accepted). This means that the hypothesized model is appropriate or suitable so that the model is able to predict the value of obesity.

Tabel 8. Chi Square Test Likehood overall fit

\begin{tabular}{cc}
\hline Iteration & -2 Log \\
& Likehood \\
\hline 1 & 5.469 \\
2 & 5.469 \\
3 & 5.469 \\
4 & 5.630 \\
5 & 7.1407 \\
\hline
\end{tabular}




\begin{tabular}{ll}
\hline 6 & 8.7910 \\
7 & 11.473 \\
\hline
\end{tabular}

Chi square test for the whole model of the data is done by comparing the value between $-2 \log$ likelihood at the beginning of the block number 0 results with the value of $-2 \log$ likelihood at the end of the block number 1 results [8]. Table 8 is a depiction of the decline in value of $-2 \log$ likelihood in this study. If there is a decrease in the value of $-2 \log$ likelihood in the results of block number 0 and block number 1 . then the model can be said to show a good regression model. In the block number 0 test where the logistic regression model only has constants. the value of $-2 \log$ likelihood is 49.4417 . When compared to the value of $-2 \log$ likelihood in block number 0 with block number 1 . the value has decreased low to reach the value of $-2 \log$ likelihood in the seventh iteration of 11.473 in block number 1 .

Tabel 9. Omnimbus test of moel coefiscients

\begin{tabular}{lllll}
\hline & & Chi- square & df & Sig. \\
\hline \multirow{3}{*}{ Step 7 } & Step & -3.526 & 1 & 0.060 \\
& Block & 72.684 & 1 & 0.000 \\
& Model & 72.684 & 1 & 0.000 \\
\hline
\end{tabular}

Testing the overall regression coefficient (overall model) of six independent variables and two control variables as a whole is done using the omnibus test of model coefficient. As explained earlier, this study uses the stepwise method. The results will be displayed in several steps where the last step will produce independent variables that affect the dependent variable. In the final step, the seventh step of this test produces one variable that affects the likelihood of a company experiencing financial distress, the ROA control variable. The value of Chi squares in Table 9 is the difference in the value of the $-2 \log$ likelihood model by only consisting of constants contained in the beginning of block 0 with the estimated model. Chi squares model value is 72.684 with df of 1 and the value of chi-squares is significant (sig 0.000 ). With an $\alpha$ level of 0.05 . the significance value is smaller than $\alpha$. Which means that the control variable. called the company's ROA, influences the financial distress condition in the company.

Table 10. Cox and snell's R Square and Nagelkerke's Square Test Results

\begin{tabular}{cccc}
\hline Step & $\begin{array}{c}-2 \text { Log } \\
\text { Likehood }\end{array}$ & $\begin{array}{c}\text { Cox \& Snell } \\
\text { R Square }\end{array}$ & $\begin{array}{c}\text { Nagelkerke's } \\
\text { Square }\end{array}$ \\
\hline 7 & 16.039 & 0.679 & 0.905 \\
\hline
\end{tabular}

The value of Cox \& Snell R Square in table 10 is 0.679 . this means that the variables contained in the logit model in this last step can explain a company experiencing financial distress or not at $67.9 \%$. Whereas based on Nagelkerke's R Square, the amount of 0.905 shows that the variability of the dependent variable. namely, financial distress. can be explained by the variability of the ROA variable of $90.5 \%$ and by other variables of $9.5 \%$ outside the model 
Table 11. Classification Table $2 \times 2$

\begin{tabular}{cccccc}
\hline \multicolumn{2}{c}{ Observed } & & \multicolumn{2}{c}{ Predicted } \\
& & & Distress & Percentage \\
& & & 0 & 1 & Correct \\
\hline Step 7 & Distress & 0 & 31 & 1 & 96.9 \\
& & 1 & 1 & 31 & 96.9 \\
& Overall & & & & 96.9 \\
\hline
\end{tabular}

Table 11 shows that out of 32 firm years that have sound financial condition (nonfinancial distress). 32 companies or $94.9 \%$ can be accurately predicted by this logistic regression model. and 1 sample is not accurately predicted by the model. whereas of 32 companies experiencing financial distressed. 32 samples or $96.9 \%$ of companies were accurately predicted by this logistic regression model. while only 1 other company was estimated to deviate from its observations. Overall it means that $32+32=64$ samples from 64 observations or $96.9 \%$ observations can be predicted accurately by this logistic regression model. The high percentage of accuracy of the classification table supports the absence of significant differences in the results of prediction data and observational data that show as a good logistic regression model.

This study uses a dependent variable, namely financial distress which has two categories (dichotomous). They are distress firms and healthy firms. In discussing corporate governance specifically. it is seen from specific aspects which include the independence board. CEO ownership. executive director ownership. family ownership. Independent audit committee. and audit committee expertise in terms of the financial condition of the affected company on financial distress. The researchers analyze the data by using the logistic regression model.

Table 12. Variables omitted in the logistic regression model

\begin{tabular}{ccccccc}
\hline Step & Variable & Coefficient & Std error & Wald stat & Df & Sig. \\
\hline 1 & FOWN & -5.4096 & 27979.0568 & 0.000 & 1 & 1.000 \\
2 & ACIND & 28.8134 & 84405.2601 & 0.000 & 1 & 0.969 \\
3 & BIND & 13.4528 & 10.7884 & 1.0892 & 1 & 0.424 \\
4 & CEOWN & -11.976 & 8989.6422 & 0.000 & 1 & 0.969 \\
5 & ACEXP & 9.7132 & 278.6364 & 0.007 & 1 & 0.680 \\
6 & LEV & 5.6217 & 4.9889 & 0.889 & 1 & 0.182 \\
\hline
\end{tabular}

Table 13. Results from Logistic regression models

\begin{tabular}{cccccc}
\hline Variable & Coefficient & Std error & Wald stat & Df & Sig. \\
\hline ROA & -62.93 & 22.9068 & 5.2829 & 1 & 0.0042 \\
Constant & -0.226 .8 & .639 & 0.1799 & 1 & 0.4284
\end{tabular}

Based on the hypothesis testing table shows that the board independence variable (BIND) has a correlation beta value of 13.4528 with a significance of 0.424 . Significance 
values above 0.05 indicate no significant effect of the BIND variable on the company's financial distress so that $\mathrm{H} 1$ is rejected.

Related to the company's ownership structure. based on the family ownership (FOWN) variable table has a correlation beta value of -5.4096 with a significance of 1.000 . The significance value above 0.05 indicates that there is no significant effect of the FOWN variable on the company's financial distress condition so that $\mathrm{H} 4$ is rejected. The CEO ownership variable (CEOWN) obtained a correlation beta value of -11.976 with a significance of 0.969 . Significance value above 0.05 indicates that there is no significant effect of CEOWN variable on the company's financial distress condition so that $\mathrm{H} 2$ and $\mathrm{H} 3$ are rejected.

Hypothesis testing results on independent variables related to internal control of the company stated that the independent audit committee variable (ACIND) obtained a correlation beta value 28.8134 with a significance of 1.000 . Significance value that is above 0.05 indicates that there is no significant effect of the ACINDP variable on the company's financial distress condition so that $\mathrm{H} 5$ is rejected. The audit committee expertise variable (ACEXP) has a correlation beta value of 9.7132 with a significance of 0.680 . The significance value above 0.05 indicates that there is no significant effect of the ACEXP variable on the company's financial distress condition so that $\mathrm{H} 6$ is rejected.

The control variable used in this study. namely leverage (LEV). Obtained a correlation beta value of 5.6217 with a significance of 0.182 . The significance value above 0.05 indicates that there is no significant effect of the LEV variable on the company's financial distress. As for the return on asset (ROA) control variable. A correlation beta value of -62.93 was obtained with a significance of 0.0042 . The significance value below 0.05 indicates a significant effect of the ROA variable on the company's financial distress. So it can be concluded. The results of the study show that companies that are in a state of distress between public companies on the Indonesia Stock Exchange are more determined by how the operations of these companies are represented by the value of the company's return on assets (ROA). Corporate governance may not be an effective measure in reducing company failures caused by distressed financial companies.

\section{Conclusion}

There is no significant effect related to the board structure, in this case board independence on the condition of financial distress experienced by the company. The insignificance of the relationship between the proportion of independent directors and the company's financial distress condition indicates that the existence of independent directors has not been able to act as an effective oversight to prevent the company from financial distress.

There is no significant effect related to the ownership structure. Namely CEO ownership. executive director ownership, and family ownership on the condition of financial distress experienced by the company. The results of this study are in line with research (Yusoff et al. 2014) which proves that ownership of company shares by CEOs. Executive directors and also family members do not have a significant impact in preventing companies from experiencing financial distress. This indicates that share ownership has not been able to work as a mechanism to resolve conflicts of interest between agents and owners.

There is no significant influence related to company internal control which includes the existence of an independent audit committee and audit committee expertise in a company on 
the condition of financial distress. It can be concluded that the company's internal control is through the existence of an audit committee.

\section{Reference}

[1] Ho. S. S. M. and Shun Wong. K.: A study of the relationship between corporate governance structures and the extent of voluntary (2001)

[2] Bambang, P dan Lina Miftahul J.: Metode Penelitian Kuantitatif Teori dan Aplikasi. In Metode Penelitian Kuantitatif Teori dan Aplikasi (2005)

[3] Vogt. W.: Explanatory Research. In Dictionary of Statistics \& Methodology (2015)

[4] Maudos. J. and Solís. L. : The determinants of net interest income in the Mexican banking system: An integrated model (2009)

[5] Elloumi. F. and Gueyié. J. P.: Financial distress and corporate governance: An empirical analysis. Corporate Governance (2001)

[6] Daily. C. M. and Dalton. D. R. : Corporate governance and the bankrupt firm: An empirical assessment (1994)

[7] Charitou. A. Lambertides. N. and Trigeorgis. L.: Managerial discretion in distressed firms. British Accounting Review (2007)

[8] Yusoff. H.. Mohamad. S. S. and Darus. F. : The Influence of CSR Disclosure Structure on Corporate Financial Performance, Evidence from Stakeholders' Perspectives, Procedia Economics and Finance (2014) 